attempts to establish the disease in experimental sites were unsuccessful, but by continuing the introduction into warren colonies in the Murray River valley into the summer months of $1950-51$, conditions favourable to success were encountered and mosquitoes rapidly spread the disease, so that by February 1951 the disease was reported widely in the Murray River system and its incidence had extended northwards along the Murrumbridgee, the Lachlan, and the Darling Rivers, almost up to the Queensland border, but with a slower spread south of the Murray.

Most effective transmission and high rabbit mortality were largely restricted to narrow zones of river frontages and to swampy areas where the duskbiting Culex annulirostris was prevalent; but it was soon evident that 'jumps' of infestation were attributable to the day-biting Aedes, which are more widely distributed over open country. Local recessions of the epidemic occurred as the autumn season advanced. The Commonwealth Scientific and Industrial Research Organization had issued recom. mendations to graziers as to how to set up fresh loci of infection by moving infected rabbits; but by June it had announced that the first great epidemic had passed, leaving a probable toll of millions of rabbits killed and a vast saving of expenditure on control measures and of valuable fodder, over an area "about half the size of the continent of Europe". While the mosquitoes had been the main agents in spreading the epidemic, it was soon recognized that the small black fly Simulium was also involved and, later, that the smaller 'true' sandflies are important carriers, especially in parts of Queensland.

Extraordinary local differences in infestation occurred, but there is little doubt that the general direction and vastness of spread were affected by the unusual distribution of conditions that had obtained. Many parts of Victoria had suffered from drought, and there was little spread of the disease south of the Murray valley; to the north, the season had been wetter and wetter, and in parts of northern New South Wales and Queensland the widths of the effective killing zones had become greater, to give almost a general epidemic. The region in which the disease had its most profound effects, namely, those areas west of the foothills of the dividing range watered by the upper tributaries of the Darling River, had experienced some of its worst flooding on record.

Obviously, many questions remain for scientific workers and graziers to answer regarding the potentialities of the disease as an agent, and the conditions under which it can be expected to exert its contribution to a general campaign of control. Plans have been made for future distribution of the virus ; but it is emphasized that there are many areas, such as high-value hilly country, where the rabbit is a serious pest, in which it can have little effect, and other measures of control must be pursued. Moreover, recovered animals have been found in some areas, possibly due to the appearance of virus strains of lower virulence; this opens up further questions for study, although in practice any acquired immunity, or variations in virulence, would only have temporary or local effects against the influence of fresh inoculations of the lethal strain.

Among notable instances of biological control, Australia has already provided the case of the pricklypear ; it may be that this further chapter in the story of the rabbit in that continent will intro. duce a record of an achievement of equal or higher rank in the annals of its pastoral and agricultural development. For the moment, it is appropriate that this chapter should end by noting (vide The Times, October 18, 1951) that three of the scientific men who had taken leading parts in the programme, Dr. I. Clunies Ross, chairman of the Commonwealth Scientific and Industrial Research Organization, Sir Macfarlane Burnett, director of the Walter and Eliza Hall Institute, and Prof. F. J. Fenner, head of the Department of Microbiology in the Australian National University, themselves were inoculated with myxomatosis to allay doubts as to possible effects of the virus on man.

J. E. Nichols

\section{RECENT RESEARCH AND ADDITIONS TO THE BRITISH FLORA}

THE flora of the British Isles is probably better known than that of any other area of comparable size, and yet important discoveries can still be made. The annual exhibition meetings of the Botanical Society of the British Isles afford opportunities for bringing new plants, and the results of recent research, to the notice of botanists, and the one held in the lecture room of the British Museum (Natural History), South Kensington, on October 20 provided ample evidence that field and herbarium work in 1951 had been exceptionally productive.

The outstanding discovery of the year was that of Diapensia lapponica L. on a Scotch mountain, thus adding a new family-the Diapensiaceæ-to the British flora. This arctic-polar species, forming dense cushion-like tufts with crowded, imbricated, cartilaginous leaves, and with peduncles some $2 \mathrm{~cm}$. tall bearing solitary white flowers $I \cdot 5-2 \mathrm{~cm}$. across, was discovered very locally by C. F. Tebbutt, an ornithologist, on a mountain top in Westerness. It was represented at the exhibition meeting by a fine series of photographs by J. E. Raven and by the specimen sent by the discoverer to the Royal Botanic Gardens, Kew, for identification.

Mr. Raven also exhibited photographs of Kcenigia islandica L., a small annual member of the Polygonacex, with a circumboreal distribution extending as far south as the Himalayas in Central Asia. This was recently detected at Kew from specimens collected in Skye in $1934^{1}$ and was re-found in June this year by Miss M. McCullum Webster. Mr. Raven's photographs showed that in Skye it grows in open damp places and that it is often gregarious. His observations and pictures indicate that it extends over a much wider area than could be deduced from the notes on the labels of the Kew specimens.

Two exhibits showed species originally recorded by G. Don (1764-1814), whose "reputed discoveries" have caused so much controversy among British botanists. Of these, the most surprising was Homogyne alpina (L.) Cass., found by A. A. P. Slack in 1951 in "the parish of Cortachy and Clova", Angus, and shown by B. W. Ribbons. Don said it occurred in the mountains of Clova "as on a rock called Garrybarns" ; but hitherto no other botanist has succeeded in re-finding it. The exhibitor is anxious to obtain evidence which will help in identifying "Garrybarns". H. alpina, formerly known as Tussilago alpina, is widespread in the mountains of Europe but 
absent from Scandinavia. The other plant originally found by Don which was represented among the exhibits was a grass, Roegneria doniana (F. B. White) Melderis (Agropyron donianum F. B. White). Since his time this has been found at intervals in the Breadalbanes $^{3}$; but it appears to have been seen prior to 1951 by only three living botanists, and the specimens taken by two of these remained unidentified until this summer. The species was illustrated by photographs taken by Mr. Raven in the Breadalbanes and also near Inchnadamph, where he rediscovered it after identification of an earlier unnamed specimen in E. S. Marshall's herbarium.

Among the rediscoveries, though of a different status from that of the Scotch plants just mentioned, must be classed B. W. Ribbons's exhibit of Acanthus mollis L. from St. Agnes, Isles of Scilly. It was recorded from here in $1851^{4}$; but was regarded as extinct until he re-found it recently on private ground in a place which may well have been the original station.

The exhibit provided by the Department of Botany of the British Museum (Natural History) illustrated other aspects of the present phase of rapidly increasing knowledge of our flora. It included, very appropriately, a selection of specimens from the Department's herbarium connected with papers recently published in Watsonia, the journal of the Botanical Society, including types of new species described therein. Among the British herbarium material displayed were: Myriophyllum verrucosum Lindley, $x$ Mentha smithiana var. angustifolia $\mathrm{R}$. Graham, Epipactis pendula C. Thomas, Rubus uatsonii W. H. Mills, Equisetum ramossisimum Desf., Epipactis cambrensis C. Thomas, Milium scabrum Merlet, Orchis cruenta Muell., and Scutellaria hastifolia L. (in sequence of publication ${ }^{5}$ ). An interesting fern exhibit was Polypodium regium as in "Hortus cliffortianus", 1737, with specimens from Vaillant and from Clitford's herbarium, and as gathered by C. E. Salmon in Teesdale in 1892 and 1911 under the name of Cystopteris alpina. It does not appear to have been seen in Britain recently. Dr. A. Melderis exhibited two British grasses, Sesleria varia (Jacq.) Wettst. and Phleum cormutatum Gaud., for comparison with the closely related foreign $S$. coerulea and $P$. alpinum with which they have long been confused in Britain.

Among the exhibits by workers at the Botany School, Cambridge, were living plants of the two species of Sesleria mentioned above, shown by Dr. S. M. Walters. The true S. coerulea (L.) Ard., which can be readily distinguished by the easily removed waxy covering to the upper leaf surface, is Scandinavian and East European; our plant, which also occurs in Iceland and Western and Central Europe, is $S$. varia (Jacq.) Wettst. The remarkable difference in the appearance of the upper leaf epidermis, including the stomata, was demonstrated with the aid of a microscope slide. Dr. Walters also exhibited live and dried material of Alchemilla subcrenata Buser recently discovered in Teesdale. This is a common European species for which previous records in the British literature were false identifications. A sheet of $A$. obtusa Buser was shown, collected in September 1951 from the only known British locality ${ }^{6}$. He also included sheets of an 'acutidens'-type Alchemilla from the Ben Lawers range which seems not to be identical with any described Scandinavian, British or Alpine species.

Also from Cambridge, D. E. Allen demonstrated the four species he recognizes in the aggregate
Cardamine pratensis in Britain. The provisional names given are: $C$. dentata Schultes $(2 n=32), C$. fragilis (Dégl. ex Lloyd) Bor. (chromosome number unknown), $C^{\prime}$. pratensis L. emend. $(2 n=56)$ and $C$. polemonioides Rouy $(2 n=64)$. The species are morphologically quite distinct, although the last two, at least, hybridize freely wherever they meet, and each has a different geographical range. Increase in chromosome number can be correlated with a more northerly range, a greater tolerance of acid soils, and a reduction in stature, in leaf-size (especially in the lamina of the upper leaflets) and in style-length. C. D. Pigott exhibited 'point' distribution maps of the three British species of Thymus based wholly on localities derived from herbarium material. It was interesting to note that further work had not greatly extended the range of the rarest species $-T$. serpyllum L. em. Mill. P. D. Sell and Dr. C. West showed specimens of eight British Hieracia, all local endemics, which had been recently rediscoverad. In some cases, for example, that of $H$. macrocarpum, more than fifty years had elapsed since their original discovery.

Recent work at University College, Leicester, was represented by several exhibits. Prof. T. G. Tutin showed Poa annua and the allied $P$. infirma and $P$. supina, with an artificial hybrid between the two first-mentioned species. $P$. infirma is now known from Cornwall ${ }^{7}$ as well as from the Channel Islands, but $P$. supina has not yet been found in Britain. Prof. Tutin also showed two subspecies of Heracleum spondylium from England. The English common plant is subspecies australe (Hartm.) Neuman, but he also found subspecies sibiricum (L.) A. and G. in Norfolk. They differ in flower, fruit and leaf ${ }^{8}$. Miss E. W. Davies had an interesting example of poly. ploidy in Primula farinosa. Swedish material examined had been found to have double the number of chromosomes of plants from Widdy Bank Fell, Durham, which differed in leaf characters. She also showed Somerset material of Carex demissa Hornem., $C$. serotina Mérat, and a suspected hybrid between them, and also an example of hybrid vigour in Asplenium adiantum-nigrum.

Blackberries have long been regarded as a puzzling critical group, and W. C. R. Watson's exhibit of Rubus villicaulis with a revised list of the series Subvirescentes is likely to make further changes necessary in British floras. In contrast, little work has been done on the species of Oxalis which occur as aliens in Britain. Dr. D. P. Young displayed herbarium material of twelve alien species in addition to the native $O$. acetosella and several varieties. Most of the names will be new to workers here. Schoenus nigricans is generally regarded as a plant subject to very little variation; but $P$. J. Newbould's dissections and diagrams show that even in this species there is much to learn. Miss J. P. Pugh showed specimens of Dryopteris borreri with the characters indicated and the allied species, from which it has been recently separated, for comparison. Her work has already shown that this fern occurs more widely than was suspected. P. F. Yeo showed a putative hybrid between Polygala calcarea and $P$. vulgaris from Somerset.

Exhibits of fresh material included twenty pots of wool aliens collected by Dr. J. G. Dony and J. E. Lousley in Bedfordshire. These were mostly of Australian origin and had been brought to Britain as seeds or fruits in wool. Some of these foreign plants are now locally common in districts where 
'shoddy', in the form of waste from woollen mills, is used as a valued manure. Most of them are very sensitive to frost and unlikely to persist as weeds. P. Greenfield showed a living plant of Cystopteris dickieana, a fern known only from sea-caves near Aberdeen, where it may be extinct.

The organization of the work of revising the Flora of Warwickshire was demonstrated by P. S. Green. This included printed cards for recorders to use in sending in records, outline maps, circulars to contributors setting out instructions for collecting material of critical groups, and the "Flora Bulletin" for circulating information about the progress of the work. Coloured drawings of plants by Miss W. M. A. Brooke, Dr. J. T. Burgess (prepared 1879-1900), Miss H. D. Garside, Miss M. Knox, Rev. W. Keble Martin, Mrs. B. H. S. Russell and Miss P. Woodlands (from the Glasgow Natural History Society), and photographs, maps, manuscripts, books and herbarium specimens from other contributors were also displayed.

The general impression which the exhibition meeting left in my mind was that work on British field botany is progressing faster than ever before. This is no doubt primarily due to the renewed interest in taxonomy at the universities, as evidenced by the exhibits. But their research is also assisting the work of other centres of study and it is helping the amateur botanist to direct his energies to more profitable channels. As a result, field botany in Great Britain has had an exceptionally successful season.

\section{J. E. LousLey}

${ }^{2}$ Burtt, B. L., Kew Bulletin, 2, 266 (1950).

- Druce, G. C., Notes R.B.G., Edin., 12, 112 (1904).

Druce, f. C., Rep. Bot. Soc. and E.C., 9, 95 (1930).

- Babington, C. C. Ann. Nat. Hist., Ser. 2, 8, 505 (1851).

${ }^{8}$ Watsonia , 1, 63, 89, 102,135, 149, 284, 345, $366(1949-50) ; 2,18$ (1951).

-Walters, S. M., Watsonia, 1, 13 (1949).

' Raven, J. E., Watsonia, 1, 357 (1950)

- Thellung, A., and Hegi, G., in Hegi, G., Ill. Fl. Mittel-Europa, $5(2), 1430$ (1926).

\section{OBITUARIES}

\section{Dr. R. G. Aitken}

WE have learned with much regret of the death on October 29, in his eighty-seventh year, of Dr. Robert Grant Aitken, director emeritus of the Lick Observatory, California. Born at Jackson, California, on December 31, 1864, Aitken was educated at Oakland High School and Williams College, Massachusetts. During 1891-95 he was professor of mathematics and astronomy in the College of the Pacific. In 1895 he joined the staff of the Lick Observatory, where he was to remain throughout his active career. William Joseph Hussey, professor of astronomy at Leland Stanford University, was at that time a volunteer observer at the Lick Observatory, and in 1896 he also was appointed to the staff. Aitken and Hussey almost at once embarked on a systematic survey of all stars down to magnitude 9.0 on the B.D. scale in the portion of the sky from the north pole to $22^{\circ}$ south declination for the detection of double stars.

The survey was made at first with the 12-in. refractor, the great 36 -in. refractor being used only to verify the duplicity of all discoveries. But soon the survey and the measures were made solely with the larger telescope. After Hussey left the Lick
Observatory in 1905 to become director of the Detroit Observatory, Aitken carried on the survey alone, and eventually completed it to $18^{\circ}$ south declination; the South African double-star observers taking over the responsibility for the remaining portion of the sky. In the course of this work, Aitken discovered 3,103 new double stars; Hussey, in his portion of the survey, had discovered 1,327. Throughout the survey an upper limit of separation of $5^{\prime \prime}$ was fixed, but for more than half the new discoveries the separation was less than $1^{\prime \prime}$.

Aitken did not restrict himself to discoveries of new binary systems. He re-measured each of his own stars at two subsequent epochs in order to detect orbital motion, while stars of special interest were observed more frequently. In the course of his work a large number of measures of known binaries, and particularly of those showing orbital motion, were made. He also computed a large number of orbits.

His observations were characterized by a high standard of accuracy, and the measurements of even the closest pairs were affected by only small accidental errors. Of special interest is the pair Aitken 88, which he discovered in 1901; the period of this binary system is only $12 \cdot 2$ years and the maximum separation $0 \cdot 17^{\prime \prime}$. Aitken observed it right round its orbit and computed the orbital elements, no other observations of this difficult pair being obtained by any other observer.

The homogeneous material obtained in this great survey was used by Aitken for various statistical studies. It is of interest to note that about one star in eighteen of those examined was capable of visual resolution as a binary star.

In 1932 Aitken published the "New General Catalogue of Double Stars within $120^{\circ}$ of the North Pole". This work was planned to supplement the "General Catalogue" published by Burnham in 1900. On his retirement from the Yerkes Observatory, Burnham had turned over the material that he had collected for the revision and extension of his catalogue to Prof. Eric Doolittle, director of the Flower Observatory. After the death of Doolittle in 1920, the whole of the material was taken over by Aitken in accordance with a promise he had made to Doolittle in 1919. In this great work is given for each pair the earliest available measure and all later measures except those quoted or referred to by Burnham. The wider and fainter pairs were omitted, however, as unlikely to be physical doubles. Aitken set a limit of separation of $10^{\prime \prime}$ for a pair with apparent magnitude of $9 \cdot 0$, with appropriate limits for brighter and fainter pairs. About thirty per cent of Burnham's pairs were thereby excluded, yet the new catalogue has 17,181 entries as compared with Burnham's 13,665 .

In 1918 Aitken published "The Binary Stars", an authoritative and comprehensive survey of every aspect of double-star astronomy, which has proved invaluable both as a text-book and as a work of reference. A revised and enlarged edition was published in 1935 .

The observation of double stars is of great importance for the information it provides about the masses of the stars. It remains one of the few fields of work in which observations (except for wide pairs) must be made visually. The glamour of astrophysics has unfortunately resulted in the almost complete neglect of double-star observations, at least in the northern hemisphere. Aitken was one of the great exponents 